\title{
Role of Medicinal plants in Covid-19 pandemic: An Ayurveda perspective
}

\author{
Review Article
}

\section{Vivek M Chaudhari1 ${ }^{*}$, Kokate K K²}

1. Assistant Professor, Department of Dravyaguna Vidnyan,

Sumatibhai Shah Ayurved Mahavidyalaya, Hadaspur. Pune.

2. Ayurved Samhita Siddhant, Ayurveda Consultant,

Shashwat Ayurveda Multi-speciality Clinic and Panchakarma Center, Katraj, Pune. India.

\begin{abstract}
The corona virus Covid-19 pandemic is the defining ongoing global health crisis situation. In Ayurveda communicable and epidemic diseases are described as Aupasargika Rogas - infectious or contagious and Janopadhvansa - pandemics respectively. The aim of this study is to review medicinal plants acting on Pranavaha Srotas and Rasavaha Srotas along with their action on signs and symptoms correlated with Covid 19. Extensive compilation and tabulation of medicinal plants is done by literary search of Brihat-trayee and their pharmacological actions from research databases. A total of 26 different medicinal plants have been enlisted. Analysis of these plants has been made as per Rasa, Anurasa, Vipaka, Veerya, Gunas and Karmas. Pharmacological actions are analyzed. Review reveals huge potential of many medicinal plants which can be used in this Covid-19 pandemic situation. This review evaluated the importance of medicinal plants described in Ayurveda literatures which can be used in the management and prevention of Covid-19.
\end{abstract}

Key Words: Corona virus, Covid-19 pandemic, Ayurveda, Aupasargika Rogas, Janopadhvansa, Medicinal plants, Pranavaha Srotas, Rasavaha Srotas.

\section{Introduction}

The corona virus Covid-19 pandemic is the defining ongoing global health crisis situation, caused by severe acute respiratory syndrome coronavirus 2 (SARS-CoV-2). Close contact person to person transmission is through respiratory droplets produced when an infected person coughs or sneezes.(1) Clinical manifestations of 2019-nCoV infection have similarities with SARS-CoV-2 where the most common symptoms include fever, dry cough, dyspnea, chest pain, fatigue and myalgia (2), (3), (4). Less common symptoms include headache, dizziness, abdominal pain, diarrhea, nausea, and vomiting (5). In Ayurveda communicable and epidemic diseases are described as Aupasargika Rogas -infectious or contagious and Janopadhvansa- pandemics respectively. (6), (7), (8), (9), (10).

\section{Root cause of Janopadhvansa}

The root cause of Janopadhvansa (pandemics) is vitiation of all the factors is Adharma (unrighteousness) and the source of this is Pragyapradha (intellectual error). People behave

* Corresponding Author:

Vivek M Chaudhari

Assistant Professor,

Department of Dravyaguna Vidnyan,

Sumatibhai Shah Ayurved Mahavidyalaya,

Hadapsar, Pune- 411028. India.

Email Id: vivekmchaudhari9982@gmail.com irresponsibly and do not take the right path and lead to sins, then people of that community deviate from their duties as well and propagate such sinful act further. Their sinful acts causes the goodness to disappear. Overall result of this is bad environmental changes which favors the infectious conditions leading to various diseases. As a result of infectious contact or ingestion of polluted food and water the whole community suffers lead to morbidity.

Factors for spread of Aupasargika Rogas (infectious or contagious diseases) (11)

- Prasangat (close interaction with the infected person), Gatrasamsparshat (physical contact with the infected person)

- Nishwas (through droplet inhalation), Sahabhojanat (sharing of food by means of contact transmission with the infected person)

- Sahashayya (sleeping in close proximity with the infected person), Asana (use of sitting arrangement used by the infected person)

- Vastra (use of clothes used by the infected person), Maalya Anulepnaat (use of cosmetics used by the infected persons)

- Ayurveda views Covid-19 disease as an attack on the Ojas (immune system) and Pranavaha Srotas (respiratory system) and Rasavaha Srotas (cardio vascular system). Covid -19 symptoms according to Ayurveda can be considered as Pranavaha and Rasavaha Sroto dushti lakshanas (signs and symptoms of vitiation of respiratory cardio vascular system). (12), (13), (14), (15), (16) 
Pathophysiology of Covid-19 disease according to Ayurveda

Nidanas (etiological factors) mentioned previously will cause Jatharagni Mandya (derangement of strength of digestive processes) and Rasa Dhatu Agni and Rakta Dhatu Agni Mandya (derangement of strength of metabolic processes) which also leads to production of Ama (a product that is an undigested form derived from food that gets absorbed into the system without proper assimilation). Due to this there will be Kapha-Vata Pradhan Tridosha Prakopa (aggravation), Dushya (vitiated body tissue) is Rasa (circulatory fluid) and Rakta (blood) affecting Pranavaha and Rasavaha Srotas. This Tridosha incriminating Rasa and Rakta Dhatu, circulates all over the body gets localized in Urasthan (chest region) and head and Indriya (sense organs) where preexisting Khavaigunya (a weak or defective part of the body) is there. This circulation of vitiated Dosha and Dushya occurs due to Sanga (acute/ chronic obstructive mechanism) and Vimargagaman (abnormal passage) and Atipravritti (hyper functional activity) mechanism. In a nut shell Tridosha in association with Rasa and Rakta Dhatu afflicting preexisting Khavaigunya in Pranavaha Srotas and Rasavaha Srotas Hridaya (Heart), Phuphusa (Lungs), head and Indriya presents with all or some of these signs and symptoms like Shushka Kaas (Dry Cough), Pratishyaya (Sneezing), Jwar (Fever), Shrama (Fatigue), Shwas (Shortness of breath), Angamarda (Muscle and joint pain), Kantha Vedana (Sore throat), Shirashoola (Headache), Chardi (Vomiting) and Atisara (Diarrhea)

Treatment should be emphasized on KaphaVata Shaman (pacification of Kapha-Vata) by virtue of Deepan (appetite enhancing), Pachana (digestion), Jwaraghana (antipyretic), Kaphanissaraka (expectoration of Phlegum), Chedan (disunion of adhered Dosha expectorant, mucolytic and bronchodilator), Pranavaha Moola Sthana Balya (strengthening), Kanthya (beneficial to Throat issues), Rasayan (rejuvenation), Hrudya (cardio tonic), and Krumighna (antimicrobial/anti-viral).
Aim of the study

- The aim of this study is to review medicinal plants acting on Pranavaha Srotas, Rasavaha Srotas and medicinal plants showing action on signs and symptoms correlated with Covid 19 with Ayurveda as a natural and safe remedy for the Covid-19 management.

- To provide scope for further study.

\section{Material and Methods}

An extensive Compilation and tabulation of medicinal plants acting on Pranavaha Srotas, Rasavaha Srotas and medicinal plants showing action on signs and symptoms correlated with Covid 19 with Ayurveda were done by literary search of Charaka Samhita, Sushruta Samhita and Ashtanga SamgrahalAshtanga Hridaya along with commentaries. Pharmacological actions from databases like Science Direct, PubMed and Google Scholar are also reviewed for the related published works. A total of 26 different medicinal plants have been enlisted from Bhavaprakasha Nighantu. Analysis of these plants have been made. Rasa (Taste), Vipaka (Post digestive effect/metabolite), Veerya (potency) and Gunas (properties) Doshghnata (pacified Dosha) have been enlisted. Pharmacological actions are analyzed. The selection of plants by authors for enlisting is based on the criteria that the extensive review of scientific and Ayurveda literature provided the basis of selection of plants having their therapeutic efficacy as anti-oxidant, anti-inflammatory, anti-viral, immune stimulant properties and possess phytochemicals which has definite role in Pranavaha Srotas, Rasavaha Srotas related symptoms and Covid-19 infection related symptoms.

\section{Observations}

Following drugs has vital role in Pranavaha Srotas and Rasavaha Srotas related issues and in turn can be used in Covid-19 symptoms. The properties of the mentioned medicinal plants are taken in to account as per Charaka Samhita, Sushruta Samhita and Ashtanga Samgraha/Ashtanga Hridaya, Bhavaprakasha Nighantu.

Table 1: Group A: Kapha Vata Shamak (balancing)

\begin{tabular}{|c|c|c|c|c|c|c|c|}
\hline $\begin{array}{c}\text { Sr } \\
\text { No. }\end{array}$ & Plant & Rasa & Vipaka & Veerya & Guna & Doshghnata & Part used \\
\hline 1 & $\begin{array}{l}\text { Kantakari } \\
\text { (Solanum } \\
\text { xanthocarpum } \\
\text { Schard. } \\
\text { Wendle) }\end{array}$ & $\begin{array}{c}\text { Katu } \\
\text { (pungent), } \\
\text { Tikta (bitter) }\end{array}$ & $\begin{array}{c}\text { Katu } \\
\text { (undergoes } \\
\text { pungent } \\
\text { taste } \\
\text { conversion } \\
\text { after } \\
\text { digestion) }\end{array}$ & $\begin{array}{l}\text { Ushna (hot } \\
\text { potency) }\end{array}$ & $\begin{array}{c}\text { Laghu (Light), } \\
\text { Ruksha (dry), } \\
\text { Tikshna } \\
\text { (Piercing) }\end{array}$ & $\begin{array}{l}\text { Kapha- Vata } \\
\text { Shamak }\end{array}$ & $\begin{array}{l}\text { Whole plant, } \\
\text { root, fruit }\end{array}$ \\
\hline 2 & $\begin{array}{c}\text { Bruhati } \\
\text { (Solanum } \\
\text { indicum Linn.) }\end{array}$ & Katu, Tikta & Katu & Ushna & $\begin{array}{c}\text { Laghu, Ruksha, } \\
\text { Tikshna }\end{array}$ & $\begin{array}{l}\text { Kapha- Vata } \\
\text { Shamak }\end{array}$ & $\begin{array}{l}\text { Whole plant, } \\
\text { root, fruit }\end{array}$ \\
\hline 3 & $\begin{array}{c}\text { Pippali } \\
\text { (Piper longum } \\
\text { Linn) }\end{array}$ & Katu & $\begin{array}{c}\text { Madhur } \\
\text { (undergoes } \\
\text { sweet taste } \\
\text { conversion } \\
\text { after } \\
\text { digestion) }\end{array}$ & $\begin{array}{l}\text { Anushna } \\
\text { (not so hot } \\
\text { so cold } \\
\text { potency) }\end{array}$ & $\begin{array}{l}\text { Laghu, Snigdha } \\
\text { (unctuous), } \\
\text { Tikshna }\end{array}$ & $\begin{array}{l}\text { Kapha Vata } \\
\text { Shamak }\end{array}$ & Fruit, Root \\
\hline
\end{tabular}




\begin{tabular}{|c|c|c|c|c|c|c|c|}
\hline 4 & $\begin{array}{c}\text { Pushkarmoola } \\
\text { (Inula } \\
\text { racemosa } \\
\text { Hook.f.) }\end{array}$ & Tikta, Katu & Katu & Ushna & $\begin{array}{c}\text { Laghu, Tikshna, } \\
\text { Ruksha }\end{array}$ & $\begin{array}{c}\text { Kapha Vata } \\
\text { Shamak }\end{array}$ & Root \\
\hline 5 & $\begin{array}{c}\text { Shathi } \\
\text { (Hedychium } \\
\text { spicatium Buch } \\
\text { Ham) }\end{array}$ & $\begin{array}{c}\text { Katu, Tikta, } \\
\text { Kashaya } \\
\text { (Astringent) }\end{array}$ & Katu & Ushna & Ruksha, Tikshna & $\begin{array}{c}\text { Kapha Vata } \\
\text { Shamak }\end{array}$ & Rhizome \\
\hline 6 & $\begin{array}{c}\text { Sunthi } \\
\text { (Zinziber } \\
\text { officinale } \\
\text { Rosc.) }\end{array}$ & Katu & Madhur & Ushna & Laghu, Snigdha & $\begin{array}{c}\text { Kapha Vata } \\
\text { Shamak }\end{array}$ & Rhizome \\
\hline 7 & $\begin{array}{c}\text { Kushtha } \\
\text { (Saussura } \\
\text { lappa (C.B } \\
\text { Clarke) }\end{array}$ & $\begin{array}{l}\text { Tikta, Katu } \\
\text { Madhur } \\
\text { (Sweet). }\end{array}$ & Katu & Ushna & $\begin{array}{c}\text { Laghu, Tikshna, } \\
\text { Ruksha }\end{array}$ & $\begin{array}{c}\text { Kapha Vata } \\
\text { shamaka }\end{array}$ & Root \\
\hline 8 & $\begin{array}{c}\text { Ashwagandha } \\
\text { Withania } \\
\text { Somnifera } \\
\text { (Linn.) Dunal. }\end{array}$ & $\begin{array}{l}\text { Tikta, Katu, } \\
\text { Madhur. }\end{array}$ & Madhur & Ushna & Laghu, Snigdha & $\begin{array}{c}\text { Kapha Vata } \\
\text { shamaka }\end{array}$ & Root \\
\hline 9 & $\begin{array}{c}\text { Kasmarda } \\
\text { (Cassia } \\
\text { occidentalis } \\
\text { Linn) }\end{array}$ & $\begin{array}{l}\text { Tikta, } \\
\text { Madhur }\end{array}$ & Katu & Ushna & $\begin{array}{c}\text { Laghu, Tikshna, } \\
\text { Ruksha }\end{array}$ & $\begin{array}{c}\text { Kapha Vata } \\
\text { shamaka }\end{array}$ & $\begin{array}{c}\text { Leaves, Seed, } \\
\text { Root }\end{array}$ \\
\hline 10 & $\begin{array}{c}\text { Bharangi } \\
\text { (Clerodendrum } \\
\text { Serratum Linn) }\end{array}$ & Tikta, Katu & Katu & Ushna & Laghu, Ruksha & $\begin{array}{c}\text { Kapha Vata } \\
\text { shamaka }\end{array}$ & Root \\
\hline 11 & $\begin{array}{c}\text { Tulasi } \\
\text { ( Ocimum } \\
\text { Sanctum Linn) }\end{array}$ & Katu, Tikta & Katu & Ushna & Laghu, Ruksha & $\begin{array}{c}\text { Kapha Vata } \\
\text { shamaka }\end{array}$ & Leaves \\
\hline 12 & $\begin{array}{c}\text { KarkatShrugi } \\
\text { (Pistacia } \\
\text { integerrima } \\
\text { Stewart ex } \\
\text { Brandis) }\end{array}$ & $\begin{array}{l}\text { Kashaya, } \\
\text { Tikta }\end{array}$ & Katu & Ushna & Laghu, Ruksha & $\begin{array}{c}\text { Kapha Vata } \\
\text { shamaka }\end{array}$ & Galls \\
\hline 13 & $\begin{array}{c}\text { Talispatra } \\
\text { (Abies } \\
\text { webbiana } \\
\text { Lindle) }\end{array}$ & $\begin{array}{l}\text { Tikta, } \\
\text { Madhur }\end{array}$ & Katu & Ushna & Laghu, Tikshna & $\begin{array}{c}\text { Kapha Vata } \\
\text { shamaka }\end{array}$ & Leaves \\
\hline 14 & $\begin{array}{c}\text { Kaiphal } \\
\text { (Myrica } \\
\text { esculenta } \\
\text { Buch-Ham) }\end{array}$ & $\begin{array}{l}\text { Kashaya, } \\
\text { Tikta, Katu }\end{array}$ & Katu & Ushna & Laghu, Tikshna & $\begin{array}{c}\text { Kapha Vata } \\
\text { shamaka }\end{array}$ & Bark \\
\hline
\end{tabular}

Table 2: Group B: Kapha Pitta Shamaka

\begin{tabular}{|c|c|c|c|c|c|c|c|}
\hline $\begin{array}{c}\text { Sr } \\
\text { No }\end{array}$ & Plant & Rasa & Vipaka & Veerya & Guna & Doshghnata & Part used \\
\hline $\mathbf{1}$ & $\begin{array}{c}\text { Vasa } \\
\text { (Adhatoda } \\
\text { vasica } \text { Nees) }\end{array}$ & $\begin{array}{c}\text { Tikta, } \\
\text { Kashaya }\end{array}$ & Katu & Sheeta & $\begin{array}{c}\text { Ruksha, } \\
\text { Laghu }\end{array}$ & $\begin{array}{c}\text { Kapha- Pitta } \\
\text { shaman }\end{array}$ & Leaf flowers \\
\hline $\mathbf{2}$ & $\begin{array}{c}\text { Hansapadi } \\
\text { (Adiantum } \\
\text { lanulatum } \\
\text { Burm.F. }\end{array}$ & Kashay & $\begin{array}{c}\text { Madhur (undergoes } \\
\text { sweet taste } \\
\text { conversion after } \\
\text { digestion) }\end{array}$ & Sheeta & Snigdha & $\begin{array}{c}\text { Kapha pitta } \\
\text { shamaka }\end{array}$ & Whole plant \\
& & & &
\end{tabular}

Table 3: Group C: Vata Pitta Shamaka

\begin{tabular}{|c|c|c|c|c|c|c|c|}
\hline $\begin{array}{l}\text { Sr } \\
\text { No }\end{array}$ & Plant & Rasa & Vipaka & Veerya & Guna & Doshghnata & Part used \\
\hline 1 & $\begin{array}{c}\text { Banafsa } \\
\text { (Viola odorata Linn.) }\end{array}$ & Katu, Tikta & Katu & Ushna & $\begin{array}{l}\text { Laghu, } \\
\text { Snigdha }\end{array}$ & $\begin{array}{l}\text { Vata Pitta } \\
\text { Shamaka }\end{array}$ & Whole plant \\
\hline 2 & $\begin{array}{c}\text { Yashtimadhu } \\
\text { (Glycyrrhiza glabra Linn.) }\end{array}$ & Madhur & Madhur & Sheeta & $\begin{array}{l}\text { Guru, } \\
\text { Snigdha }\end{array}$ & $\begin{array}{l}\text { Vata Pitta } \\
\text { Shamak }\end{array}$ & Root \\
\hline 3 & $\begin{array}{c}\text { Guduchi } \\
\text { (Tinospora cordifolia Willld) }\end{array}$ & Tikta, Kashaya & Madhur & Ushna & $\begin{array}{l}\text { Laghu, } \\
\text { Snigdha }\end{array}$ & $\begin{array}{l}\text { Vata-Pitta- } \\
\text { Kapha Shamak }\end{array}$ & Stem \\
\hline 4 & $\begin{array}{c}\text { Dalchini } \\
\text { (Cinnamomum zeylanicum } \\
\text { Blum) }\end{array}$ & $\begin{array}{c}\text { Kashaya, Tikta, } \\
\text { Madhur }\end{array}$ & Katu & Ushna & $\begin{array}{l}\text { Laghu, } \\
\text { Tikshna, } \\
\text { Ruksha }\end{array}$ & $\begin{array}{l}\text { Vata Pitta } \\
\text { Shamaka }\end{array}$ & Bark \\
\hline
\end{tabular}


Tejapatra

\begin{tabular}{|c|c|c|c|c|c|c|c|}
\hline 5 & $\begin{array}{c}\text { Tejapatra } \\
\text { (Cinnamomum tamala Nees } \\
\text { \& Eberm) }\end{array}$ & Katu, Tikta & Katu & Ushna & $\begin{array}{l}\text { Laghu, } \\
\text { Tikshna, } \\
\text { Ruksha }\end{array}$ & $\begin{array}{l}\text { Vata Pitta } \\
\text { Shamaka }\end{array}$ & Leaves \\
\hline 6 & $\begin{array}{c}\text { Khatmi } \\
\text { (Althaea officinalis Linn) }\end{array}$ & Madhur & Madhur & Sheeta & $\begin{array}{c}\text { Snigdha, } \\
\text { Pichhil, } \\
\text { Guru }\end{array}$ & $\begin{array}{l}\text { Vata Pitta } \\
\text { Shamaka }\end{array}$ & Roots \\
\hline
\end{tabular}

Table 4: Group D: Tridosha Shamaka

\begin{tabular}{|c|c|c|c|c|c|c|c|}
\hline $\begin{array}{l}\text { Sr } \\
\text { No }\end{array}$ & Plant & Rasa & Vipaka & Veerya & Guna & Doshghnata & Part used \\
\hline 1 & $\begin{array}{c}\text { Haridra } \\
\text { (Curcuma longa Linn) }\end{array}$ & Tikta, Katu & Katu & Ushna & $\begin{array}{l}\text { Laghu, } \\
\text { Ruksha }\end{array}$ & $\begin{array}{l}\text { Vata-Pitta- } \\
\text { Kapha } \\
\text { Shamaka }\end{array}$ & Rhizome \\
\hline 2 & $\begin{array}{c}\text { Haritaki } \\
\text { (Terminalia chebula } \\
\text { (Retz) Lyons) }\end{array}$ & $\begin{array}{l}\text { Kashay, Madhur, } \\
\text { Amla, Katu, Tikta }\end{array}$ & Madhur & Ushna & $\begin{array}{l}\text { Laghu, } \\
\text { Ruksha }\end{array}$ & $\begin{array}{l}\text { Vata-Pitta- } \\
\text { Kapha } \\
\text { Shamaka }\end{array}$ & Fruit \\
\hline 3 & $\begin{array}{c}\text { Amalaki } \\
\text { (Embelica officinalis } \\
\text { Gaertn) }\end{array}$ & $\begin{array}{c}\text { Amla, Kashay, } \\
\text { Madhur, } \\
\text { Katu, Tikta }\end{array}$ & Madhur & Sheeta & $\begin{array}{l}\text { Guru, } \\
\text { Ruksha, } \\
\text { Sheeta }\end{array}$ & $\begin{array}{l}\text { Vata-Pitta- } \\
\text { Kapha } \\
\text { Shamaka }\end{array}$ & Fruit \\
\hline 4 & $\begin{array}{c}\text { Ela } \\
\text { (Elettaria cardimomum } \\
\text { Maton) }\end{array}$ & Katu, Madhur & Madhur & Sheeta & $\begin{array}{l}\text { Laghu, } \\
\text { Ruksha }\end{array}$ & $\begin{array}{l}\text { Vata-Pitta- } \\
\text { Kapha } \\
\text { Shamaka }\end{array}$ & Seeds \\
\hline
\end{tabular}

\begin{tabular}{|l|l|}
\hline $\begin{array}{l}\text { Sr. } \\
\text { No. }\end{array}$ & Plant \\
\hline $\mathbf{1}$ & $\begin{array}{l}\text { Kantakari } \\
\text { (Solanum xanthocarpum Schard } \\
\text { Wendle) }\end{array}$ \\
\hline $\mathbf{2}$ & $\begin{array}{l}\text { Bruhati } \\
\text { (Solanum indicum } \text { Linn.) }\end{array}$ \\
\hline $\mathbf{3}$ & $\begin{array}{l}\text { Pippali } \\
\text { (Piper longum } \text { Linn) }\end{array}$ \\
\hline $\mathbf{4}$ & $\begin{array}{l}\text { Pushkarmoola } \\
\text { (Inula racemosa } \text { Hook.f.) }\end{array}$ \\
\hline $\mathbf{5}$ & $\begin{array}{l}\text { Shathi } \\
\text { (Hedychium spicatum } \text { Buch Ham) }\end{array}$ \\
\hline
\end{tabular}

$6 \quad$ Sunthi

(Zinziber officinale Rosc.)

\section{$7 \quad$ Kushtha}

(Saussura lappa (C.B Clarke)

\begin{tabular}{l|l}
$\mathbf{8}$ & $\begin{array}{l}\text { Ashwagandha } \\
\text { (Withania Somnifera (Linn.) Dunal.) }\end{array}$ \\
\hline 9 & $\begin{array}{l}\text { Kasmarda } \\
\text { (Cassia occidentalis Linn) }\end{array}$ \\
\hline $\mathbf{1 0}$ & $\begin{array}{l}\text { Bharangi } \\
\text { (Clerodendrum Serratum (Linn) }\end{array}$
\end{tabular}

$11 \quad$ Tulasi

( Ocimum Sanctum Linn)

\section{KarkatShrugi \\ (Pistacia integerrima Stewart ex Brandis)}

\section{Talispatra}

(Abies webbiana Lindle)

\begin{tabular}{l|l}
14 & $\begin{array}{l}\text { Kaiphal } \\
\text { (Myrica esculenta } \text { Buch-Ham) }\end{array}$ \\
\hline 15 & Vasa (Adhatoda vasica Nees)
\end{tabular}

Table 5: Pharmacological actions of drugs Pharmacological actions

Antihistaminic (17), anti-allergic (18), cardio tonic (19), antioxidant (20), immunomodulatory (21)

laxative and cardio tonic (22), hepatoprotective (23), antioxidant (24), antiinflammatory and antipyretic (25), antihypertensive (26), cardio-protective (27) cardio protective (28), antioxidant (29), hepatoprotective (30), anti-inflammatory (31) cardio protective (32), anti- allergic (33), anti-inflammatory \& analgesic (34), adrenergic beta blocking activity (35)

anti-inflammatory (36), anti-asthmatic (37), hepatoprotective (38), antioxidant (39), antibacterial (40) nootropic effects and memory restorative activity (41), tranquilizing (42)

anti-emetic (43), anti-diabetic and hypolipidaemic(44), antibacterial (45), antioxidant (46), antitussive (47), antiviral (48), analgesic and antiinflammatory (49), cardio protective (50), antioxidant (51), gastro protective (52)

anti-inflammatory (53), hepatoprotective (54), anti-ulcer and cholagogic (55), immunomodulatory (56), gastro-protective (57), spasmolytic (58), antidiarrheal (59), antiviral (60), cardio tonic (61)

anti-inflammatory (62), anti-stress (63), immunomodulatory (64),

antioxidant (65), cardio protective (66)

antioxidant (67), hepatoprotective (68), analgesic and antipyretic (69), antianxiety and antidepressant (70), antiasthamatic (71)

antioxidant (72), anti-inflammatory and antipyretic (73),

bronchodilator (74), allergic asthma(75), antioxidant, antiangiogenic and vasorelaxant activities (76)

antioxidant (77), immunomodulatory (78), anti-inflammatory (79), antipyretic (80), antihypertensive and cardio protective (81), hepatoprotective (82), antistress (83)

antioxidant (84), analgesic, anti-inflammatory (85), antiasthamatic (86)

antitussive (87), anti-inflammatory and sedative (88),

antispasmodic, bronchodilator and antiplatelet (89),

antipyretic (90), antioxidant and antimicrobial properties (91)

antioxidant, anti-inflammatory and analgesic (92), anti-allergic (93), anxiolytic (94), antihypertensive (95), antidiarrheal (96)

anti-asthmatic and bronchodilator activity (97), anti-allergic (98), antioxidant (99), cardio protective (100), antipyretic (101) 


\begin{tabular}{|l|l|}
16 & $\begin{array}{l}\text { Hansapadi } \\
\text { (Adiantum lanulatum } \text { Burm.F.) }\end{array}$ \\
\hline 17 & $\begin{array}{l}\text { Banafsa } \\
\text { (Viola odorata } \text { Linn.) }\end{array}$ \\
$\mathbf{1 8}$ & $\begin{array}{l}\text { Yashtimadhu } \\
\text { (Glycyrrhiza glabra } \text { Linn.) }\end{array}$ \\
\hline
\end{tabular}

19

Guduchi

(Tinospora cordifolia (Willd)

20

Dalchini

( Cinnamomum zeylanicum Blum)

21 Tejapatra

(Cinnamomum tamala Nees \& Eberm)

22

23

24

\author{
Khatmi \\ (Althaea officinalis Linn) \\ Haridra \\ (Curcuma longa Linn) \\ Haritaki
}

(Terminalia chebula (Retz) Lyons)

25

Amalaki

(Embelica officinalis Gaertn)

26

\section{Ela}

(Elettaria cardimomum Maton) antibacterial (102), hepatoprotective and antioxidant (103)

anti-asthmatic (104), antipyretic (105), antihypertensive and anti dyslipidemc (106), anti-inflammatory (107)

antitussive and expectorant (108), anti-bacterial anti-oxidant (109), antithrombotic (110), memory enhancing activity (111), antiviral (112), antiinflammatory and anti-ulcer (113), immunomodulatory (114), antistress (115) neuroprotective (116), antidiarrheal and antiulcer (117), analgesic (118), antiinflammatory (119), cardio protective (120), antidepressant (121), antiasthamatic (122), antipyretic (123), anti-allergic (124), antioxidant (125) antioxidant and antimicrobial (126), antihypertensive and vasorelaxant (127), antiviral (128), antidepressant and anti-anxiety (129), antipyretic (130) antidiarrheal (131), antioxidant (132), anti-inflammatory, analgesic and antipyretic (133), nephroprotective (134), immunomodulatory (135), anxiolytic, antidepressant, and anti-stress activities (136), antiviral (137), cardio protective (138)

antitussive (139), antioxidant (140), analgesic and anti-inflammatory (141), cardio protective (142), antiviral (143)

anti-inflammatory (144), hepatoprotective (145), antioxidant (146), cardio protective (147), antiviral (148), antidepressant (149), antipyretic (150) antimicrobial (151), antiviral (152), antioxidant (153), cardio protective (154), immunomodulatory (155), antitussive (156), antipyretic (157), antiallergic (158)

antipyretic (159), antidepressant (160), antioxidant (161), anti-inflammatory (162), antiviral (163), hepatoprotective (164), cardio protective (165), antitussive (166)

antibacterial (167), gastro protective (168), antihypertensive (169), antioxidant (170), antispasmodic (171)

\section{Discussion}

\section{Among group A - Kapha Vata Shamak}

Katu Tikta Rasa and Katu Vipaka plants are Kantakari, Bruhati, Pushkarmoola, Kushtha, Kasmarda, Bharangi, Tulasi, Karkatshrugi and Kaiphal is Kashay Pradhan Tikta Katu Rasa and Katu Vipaka, Talispatra is Tikta Pradhan Madhur Rasa Katu Vipaka, Karkatshrugi Kashay Pradhan Tikta Rasa and Katu Vipaka, Kasmarda Tikta Pradhan Madhur Rasa and Katu Vipaka, Kushtha Tikta Pradhan Katu Rasa and Katu Vipaka and Ashwagandha is Tikta Pradhan Katu and Madhur Rasa and Madhur Vipaka while Sunthi and Pippali has Katu Rasa and Madhur Vipaka.

Among these maximum plants possess Laghu Ruksha properties, only Pippali and Sunthi possesses Snigdha Guna while Kantakari, Bruhati, Pippali, Pushkarmoola, Kushtha, Kasmarda, Talispatra, Kaiphal possesses Tikshna Guna and all possess Ushna Potency.

So by Katu Tikta Rasa and Laghu Ruksha Guna and Ushna Veerya Deepan of Jatharagni (appetite enhancing and Dhatvagni (tissue metabolism) is achieved Pachana (digestion) of Ama.

Tikta Rasa and Laghu Ruksha Guna combination acts as Rasadhatvagni Vardhan and Ama Pachana resulting in Jwaraghana action. Tikta Rasa of the drug due to their Vishaghna (neutralizes toxins) and Krumighna property reduces the incidence and manifestation of allergy and infection of microorganism like virus and bacteria.

Laghu Ruksha Guna and Ushna Veerya does Kaphanissaraka Karma while Tikshna along with Laghu Ruksha and Ushna Guna does Chedan. Thus obstruction made by Kapha in the Pranavaha Srotas is relieved by Sroto- Marga Vivrunoti (bronchodilation) and Srotoshodhana (purification of channels) and Vata Anulomana (normal direction or downward movement) is achieved. Among these Pippali, Sunthi and Ashwagandha possess Madhur Vipaka Snigdha Guna which gives Bala (strength) Pranavaha Srotas Moolasthan (anatomical seat of channel) and do Rasayan Karma.

\section{Group B - Kapha Pitta Shamaka}

Vasa is Tikta, Kashaya, Katu Vipaka and Sheeta has Ruksha, Laghu Guna.

It has Swarya (soothing to the Throat/good for voice) property- Vasa by its Tikta, Kashaya, Katu Vipaka and Ruksha, Laghu Guna eliminates Kapha which is Adhered to Kantha (Throat) by its Scrapping action ultimately Shotha (inflammation) is relieved Sroto-Marga Vivrunoti and Srotoshodhana is achieved and action of Swarayantra (Larynx and Pharynx) is reestablished. Also by its properties mainly by Kashay Rasa and Laghu Ruksha and Sheeta Gunas it helps Wound healing at Respiratory system caused by excessive Pitta. By its Kashay Rasa and Sheeta Veerya and Sheeta Guna it acts on Hemoptysis and also Sadhak Pitta Shaman is achieved thus does Hrudya (Cardio tonic) Karma. Chemical component vasicine which is present in the leaves, roots and flowers found to have the pharmacological properties like - bronchodilator activity, expectorant, respiratory stimulant activity.

Hansapadi - Kashay Rasa, Madhur Vipaka, Sheeta and Snigdha Gunas increases the Bala does Dhatu Vardhan (tissue promotion), Rakta Prasadan (blood purification) and Oja Vardhan (promotion of health). Gives Strength to the Heart (Hrudya) by Mansa Dhatu Bala Vardhan (muscle strengthening). 
Rasayan property of drug also revitalizes and establishes good quality of Sharira Dhatu (body tissues).

\section{Group C- Vata Pitta Shamak}

Among these maximum plants possess Laghu property only Yashtimadhu and Khatmi possesses Guru Guna while Yashtimadhu, Khatmi, Banafsa has Snigdha property and Tejapatra, Dalchini possesses Ruksha Guna while Tejapatra and Dalchini possess Tikshna Potency.

So by Katu Tikta Rasa and Laghu Ruksha Guna and Ushna Veerya Deepan of Jatharagni and Dhatvagni is achieved Pachana of Ama is done.

Tikta rasa and Laghu Ruksha Guna combination acts as Rasadhatvagni Vardhan and Ama Pachana resulting in Jwaraghana action. Tikta Rasa of the drug due to their Vishaghna and Krumighna property reduces the incidence and manifestation of allergy and infection of microorganism like virus and bacteria.

Laghu Ruksha Guna and Tikshna Guna and Ushna Veerya does Kaphanissaraka Karma while Tikshna along with Laghu Ruksha and Ushna Guna does Chedan. Thus obstruction made by Kapha in the Pranavaha Srotas is relieved by Sroto-Marga Vivrunoti and Srotoshodhana and Vata Anulomana is achieved. Among these Yashtimadhu, Khatmi possess Madhur Vipaka Snigdha Guna which gives Bala Pranavaha Srotas Moolasthan and do Rasayan Karma. Yashtimadhu shows Jeevaniya Karma (Longevity promoter) by its action on Rakta Dhatu and Rasayan Karma ultimately improvises Oja Dhatu. Yashtimadhu is good drug in bleeding disorders to stop bleeding (Shonitsthapan Karma).

\section{Group D - Tridosha Shamak}

In this group Guduchi, Haridra and Haritaki has Ushna Veerya while Amalaki and Ela possess Sheeta Veerya. All show Madhur Vipaka except Haridra shows Katu Vipaka. These Tridosha Shamak drugs by their Rasayan property increase quality and Quantity of all Dhatus. In Pranavaha Srotas related signs and symptoms they increase the Bala of organs associated with Pranavaha Srotas. Amalaki is known for its Vayasthapan Karma that means it acts on Aging process by slowing down accelerated aging process by its free radical scavenging process (172). Haritaki, Amalaki and Ela by its Anulomana Karma (normal direction or downward movement act) on Mala. Regular evacuation of Mala after Deepan and Pachana helps in restoration of Dosh and Dhatu. More specifically Anulomana of Apan Vayu helps in restoration of Prakrut Gati and functions of Prana, Udan, Saman and Vyan Vayu. Heart and Lungs and other parts of Pranavaha Srotas are mainly made up of Rakta Dhatu. Phuphusa is made up of Rakta and Phena. Phena means bubbles or froth of Rakta Dhatu. Heart is made up of essence of Rakta and Kapha. Guduchi and Haridra Tikta, Katu Rasa and Ushna Veerya does Ama Pachana, Kleda Shoshana thus minimizes Fibrotic changes occurring in Lungs. Guduchi and Haridra has action on Rakta Dhatu. It increases Rakta Dhatvagni and pacifies Kapha related issues there by helps in production of quality Rakta Dhatu and maintains functioning of organs which are made of Rakta Dhatu and Kapha.

Enlisted plants showed antihistaminic, ant allergic, cardio tonic, antioxidant, immunomodulatory, hepatoprotective, anti-inflammatory, antipyretic, antiasthmatic, antitussive, antidiarrheal, antiviral, antistress, antianxiety, antidepressant, nephroprotective, antihypertensive in preclinical and clinical studies.

Medicinal plants, which were reviewed, possess properties like Jatharagni Vardhan and Dhatvagni Vardhan, Pachana of Ama, Krumighna, Kaphanissaraka, Chedan, Balya, Rasayan Karma, Hrudya, Oja Vardhan, Jeevaniya Karma, Shonitsthapan Karma, Vrana Ropak (wound healing and anti-ulcer genic), Shothahara (anti-inflammatory), Jwaraghana (anti-pyretic).

In the treatment of Jwar, which is major symptom seen in Covid 19, it is clearly mentioned that when Agni is stabilized, Bala and Ojas are increased (173). It has been pointed out that Bala by itself can bring back the balance of the Doshas (174). Strengthening the host immunity would be an important therapeutic strategy from the Ayurveda viewpoint. Medicinal plants possessing Jatharagni Vardhan and Dhatvagni Vardhan and Ama Pachana properties can play vital role in this situation. It has been observed that a robust immune response across different cell types was associated with clinical recovery, similar to what we see in influenza, in COVID-19 cases also (175). As the disease progresses, the efficiency of Ojas is compromised and a crisis can develop. Such a presentation is seen in critical COVID 19 cases, characterized by disruption of immune system (176). The word 'Rasayan (Rasa + ayana)' refers to nutrition and its transportation in the body for attaining excellent Dhatu; which leads to gain longevity, freedom from disorders, optimum strength of physique and sense organs (177). Rasayan promotes nutrition by explicitly enriching the nutritional value of Rasa by enhancing Agni, i.e. digestion, metabolism, and absorption. Medicinal plants showing Balya, Rasayan Karma and Oja Vardhan properties can improve immune response in Covid-19 cases. Signs and symptoms related with Respiratory system can be relieved by use of medicinal plants showing properties like Kaphanissaraka, Hrudya, Shonitsthapan, Vrana Ropak, Shothahara and Jwaraghana properties. As Covid-19 is a viral disease medicinal plants showing Krumighna properties can minimize or nullify viral load and associated other infective foci effectively. Considering digestion related issues plants showing Jatharagni Vardhan and Dhatvagni Vardhan and Ama Pachana properties can relieve symptoms like headache, abdominal pain, diarrhea, nausea and vomiting. Psychological wellbeing is also important aspect in disease progression or recovery. Plants showing anti-stress, antianxiety, antidepressant activities can address these issues. There are research findings showing multi organ failures due to Covid-19 (178) Medicinal plants showing cardio tonic, 
hepatoprotective, nephroprotective action can prevent organ damage.

Ayurveda takes a holistic approach toward treatment that integrates mind, body, and soul, and also taking in to account of individual constitution as well as seasons. Medicines should be planned as per individuals Dosh, Dhatu, Mala vitiation status, locality of individual and disease on body, strength of individual and infection, season of infection and whether it is chronic or acute, digestive power, Prakruti (individual constitution), age, strength of mind or tolerance of an individual, food and activities to which individual is accustomed to, food habits and stages of disease (179).

\section{Conclusion}

In the present review, we have discussed the possible potential uses of medicinal plants to prevent or even treat COVID-19 symptoms. Decision regarding to whom and which medicinal plant can be used as a single herb or in combination with other herbs considering signs and symptoms of individual infected person can be taken with the holistic approach of Ayurveda. We can conclude that enlisted plants can play crucial role in the management of Covid-19 pandemic.

\section{References}

1. Kramer A, Schwebke I, Kampf G. How long do nosocomial pathogens persist on inanimate surfaces? A systematic review. BMC Infectious Diseases 2006;6(1):130. Available from: https:// www.researchgate.net/publication/6873698

2. Huang $\mathrm{C}$, Wang $\mathrm{Y}$, Li X, Ren L, Zhao J, Hu $\mathrm{Y}$, et al. Clinical features of patients infected with 2019 novel coronavirus in Wuhan, China. Lancet 2020;395. Available from: https:// www.researchgate.net/publication/338806634

3. Wang D, Hu B, Hu C, Zhu F, Liu X, Zhang J, et al. Clinical characteristics of 138 hospitalized patients with 2019 novel coronavirus-infected pneumonia in Wuhan, China. JAMA 2020;323(11):1061-69. Available from https://www.ncbi.nlm.nih.gov/pmc/articles/ PMC7042881

4. Zhu N, Zhang D, Wang W, Li X, Yang B, Song $\mathrm{J}$, et al. A novel coronavirus from patients with pneumonia in China, The New England journal of medicine 2019;382(8):727-33. Available from https://pubmed.ncbi.nlm.nih.gov/31978945

5. Huang C, Wang Y, Li X, Ren L, Zhao J, Hu $\mathrm{Y}$, et al. Clinical features of patients infected with 2019 novel coronavirus in Wuhan, China. Lancet 2020;395(10223):497-506. Available from https://www.thelancet.com/journals/lancet/article/ PIIS0140-6736(20)30183-5

6. Acharya PS, editor. Charaka Samhita of Agnivesha. Vimana Sthana. Ch. 3. Ver.6. Reprint ed. Varanasi: Chaukhamba Surbharti Prakashan; 2008. p. 315.

7. Acharya PS, editor. Charaka Samhita of Agnivesha. Vimana Sthana. Ch. 3. Ver.7-11.
Reprint ed. Varanasi: Chaukhamba Surbharti Prakashan; 2008. p. 316.

8. Acharya PS, editor. Charaka Samhita of Agnivesha. Vimana Sthana. Ch. 3. Ver.20. Reprint ed. Varanasi: Chaukhamba Surbharti Prakashan; 2008. p. 317.

9. Acharya PS, editor. Charaka Samhita of Agnivesha. Vimana Sthana. Ch. 3. Ver.21-23. Reprint ed. Varanasi: Chaukhamba Surbharti Prakashan; 2008. p. 318.

10. Shastri A, editor. Sushruta Samhita of Sushruta. Sharir Sthana. Ch. 09, Ver. 12. Reprint ed. Varanasi: Chaukhamba Sanskrit Sansthan; 2007. p. 96.

11. Shastri A, editor. Sushruta Samhita of Sushruta. Sharir Sthana. Ch. 09, Ver. 12. Reprint ed. Varanasi: Chaukhamba Sanskrit Sansthan; 2007. p. 96.

12. Acharya PT, editor. Charaka Samhita of Agnivesha. Vimana Sthana. Ch. 5. Ver.10-13. Reprint ed. Varanasi: Chaukhamba Surbharti Prakashan; 2008. p. 330.

13. Acharya PS, editor. Charaka Samhita of Agnivesha.Vimana Sthana. Ch. 5. Ver.10-13. Reprint ed. Varanasi: Chaukhamba Surbharti Prakashan; 2008. p. 331.

14. Acharya PS, editor. Charaka Samhita of Agnivesha. Sutra Sthana. Ch. 28. Ver.09-10. Reprint ed. Varanasi: Chaukhamba Surbharti Prakashan; 2008. p. 228.

15. Acharya PS, editor. Charaka Samhita of Agnivesha. Vimana Sthana. Ch. 5. Ver.26-27. Reprint ed. Varanasi: Chaukhamba Surbharti Prakashan; 2008. p. 333.

16. Shastri A, editor. Sushruta Samhita of Sushruta, Sharir Sthana. Ch. 09, Ver. 12. Reprint ed. Varanasi: Chaukhamba Sanskrit Sansthan; 2007. p. 96.

17. Vadnere GP, Gaud RS, Singhai AK. Therapeutic effect of ethanolic extract of SX i.e. asthma relieving or antihistaminic, antiallergic property. Pharmacologyonline 2008;1:513-22. Available from: https://www.researchgate.net/publication/ 267367491

18. Vadnere GP, Gaud RS, Singhai AK. Therapeutic effect of ethanolic extract of SX i.e. asthma relieving or antihistaminic, antiallergic property. Pharmacologyonline 2008;1:513-22. Available from: https://www.researchgate.net/publication/ 267367491

19. Pasnani JS, Hemavathi KG, Rajani AP, Gulati OD. Abana, a polyherbal formulation on isoproterenolinduced myocardial infarction in rats. $J$ Ethnopharmacol 1988;24:287-302 . Available from: https://www.researchgate.net/publication/ 44680230

20. Kumar S, Sharma UK, Sharma AK, Pandey AK. Protective efficacy of Solanum xanthocarpum root extracts against free radical damage: Phytochemical analysis and antioxidant effect. Cell Mol Biol (Noisy-le-grand) 2012;58:174-81. 
Available from: https://www.researchgate.net/ publication/234009878

21. Sultana R, Khanam S, Devi K. Immunomodulatory effect of methanol extract of Solanum xanthocarpum fruits. Int J Pharma Sci Res 2011;2:93-7. Available from: https:// www.ncbi.nlm.nih.gov/pmc/articles/PMC4078473

22. Deb P, Das L, Ghosh R, Debnath R, Bhakta T. Evaluation of laxative and cardiotonic activity of Solanum indicum linn. Fruits. J Pharm Phytother 2013;1:11-14. Available from: https:// www.researchgate.net/publication/301230195

23. Simon RP, Patel HV, Kiran K. Hepatoprotective activity of some plants extract against paracetamol induced hepatotoxicity in rats. Journal of Herbal Medicine and Toxicology 2010;4(2):101-06. Available from: https://www.researchgate.net/ publication/215449438

24. Hasan R, Prabhat $P$, Shafaat $K$, Khan R. Phytochemical investigation and evaluation of antioxidant activity of fruit of Solanum indicum Linn. International Journal of Pharmacy and Pharmaceutical Sciences 2013;5: 237-42. Available from: https://www.researchgate.net/publication/ 267036297

25. Deb P, Ghosh R, Chakraverty R, Rajkumar DL, et al. Phytochemical and Pharmacological Evaluation of Fruits of Solanum indicum Linn. Int. J. Pharm. Sci. Rev. Res. 2014; 25(2):28-32. Available from: https://www.researchgate.net/publication/ 278730597

26. Bahgat A, Abdel-Aziz H, Raafat M, Mahdy A, ElKhatib AS, et al. Solanum indicum ssp. distichum extract is effective against L-NAME-induced hypertension in rats. Fundam Clin Pharmacol. 2008;22(6):693-9. Available from: https:// www.researchgate.net/publication/320331018

27. Deb PK, Das L, Ghosh R, Debnath R, Bhakta T. Evaluation of laxative and cardiotonic activity of Solanum indicum Linn. fruits. J Pharm Phytother 2013b;1(3):11-4. Available from: https:// www.researchgate.net/publication/320331018

28. Chauhan K, Lalkrishna, Parmar R S, Kagathara V, Madat D, Patel T. Effect of Piper longum linn on histopathological and biochemical changes in isoproterenol induced myocardial infarction in rats. Research Journal of Pharmaceutical, Biological and Chemical Sciences 2010;1(3):759. Available from: https://www.researchgate.net/publication/ 285754940

29. Verma,P, Sutrakar.S, Dyslipidemic and Antioxidant activity of Piper longum extract in hyperlipemic rats. Research Journal of Pharmacy and technology 2015;8(12):1609-14. Available from: https:// www.researchgate.net/publication/288992442

30. Koul IB , Kapil A . Evaluation of the liver protective potential of piperine, an active principle of black and long peppers Planta Med 1993;59:413-17. Available from: https:// pubmed.ncbi.nlm.nih.gov/8255933

31. Kumar A, Panghal S, Mallapur SS, Kumar M, Ram V, Singh BK. Antiinflammatory Activity of Piper longum Fruit Oil. Indian $\mathrm{J}$ Pharm Sci. 2009;71(4):454-6. Available from: https:// www.ncbi.nlm.nih.gov/pmc/articles/PMC2865823

32. Chabukswar A.R. Kuchekar, B.S. Jagdale, SC Lokhande, PD Raut. Cardioprotective activity of Inula racemosa Int J Chem Sci 2010;8(3):1545-52. Available from: https://www.researchgate.net/ publication/6487906

33. Srivastava S, Gupta PP, Rajendra Prasad, RC Saxena. Evaluation of Antiallergic activity (Type 1 hypersensitivity) of Inula racemosa in Rats, Indian J Physiol Pharmacol 1999;43(2):235-41. Available from: https://pubmed.ncbi.nlm.nih.gov/10365318

34. Arumugam P, Marudhamuthu M, Thangaraj N. Evaluation of anti-inflammatory and analgesic effects of aqueous extract obtained from root powder of Inula racemosa Hook. f. Internat J Adv Res Life Sci 2013;1(3):43-7. Available from: http:// www.academicjournals.org/article/ article1380789804

35. Tripathi YB, Tripathi P, Upadhyay BN. Assessment of the adrenergic beta-blocking activity of Inula racemosa. J Ethnopharmacol. 1988;23(1):3-9. Available from: https://pubmed.ncbi.nlm.nih.gov/ 2901513

36. Srimal R, Sharma S, Tandon JS. Anti-inflammatory and other pharmacological effects of Hedychium spicatum (Buch-Hem). Indian Journal of Pharmacology 1984;16:143. Available from: https://www.semanticscholar.org/paper/Antiinflammatory-and-other-pharmacological-effects-

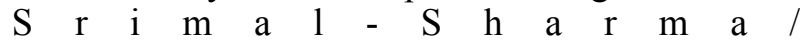
d36f98448589d7cc268194d14406cba36af92991

37. Chaturvedi GN, Sharma BD. Clinical studies on Hedychium spicatum (Shati): An antiasthmatic drug. J Res Indian Med 1975;10:6- 8. Available from: https://www.ncbi.nlm.nih.gov/pmc/articles/ PMC3530335

38. Habbu PV, Hukkeri VI, Kulkarni R, Marihal SC. Screening of Hedychium Spicatum for hepatoprotective activity in albino rats. Indian Drugs 2002;39. Available from: https:// www.researchgate.net/publication/272025905

39. Sravani T, Paarakh P. Antioxidant activity of Hedychium spicatum Buch.-Ham. rhizomes. Indian Journal of Natural Products and Resources 2012;3:354-58. Available from: https:// www.researchgate.net/publication/286020029

40. Bisht GS, Awasthi AK, Dhole TN. Antimicrobial activity of Hedychium spicatum. Fitoterapia 2006;77(3):240-2. Available from: https:// pubmed.ncbi.nlm.nih.gov/16530343

41. Shete RV, Bodhankar S. Hedychium spicatum : evaluation of its nootopic effect in mice. Res $\mathrm{J}$ Pharmacog Phytochem 2010;2:403-06. Available from: https://www.semanticscholar.org/paper/ Hedychium-spicatum\%3 A-Evaluation-of-ItsNootropic-in-Shete-Bodhankar/ 2a59dc27e7bfd5ab1e475d29748338ee6c42f057

42. Dixit VK, Varma KC. Effect of essential oil of rhizome of Hedychium coronarium and Hedychium spicatum on central nervous system. Indian $\mathrm{J}$ 
Pharmacol 1979;11:147- 49. Available from https://www.academia.edu/36205845

43. Ernst E, Pittler MH. Efficacy of ginger for nausea and vomiting: a systematic review of randomized clinical trials. Br. J. Anesth, 2000;84(3):367-71. Available from: https://pubmed.ncbi.nlm.nih.gov/ 10793599

44. Al-Amin, Zainab M. Anti-diabetic and hypolipidaemic properties of ginger (Zingiber officinale) in streptozotocin-induced diabetic rats. Br. J. Nut. 2006;96:660-66. Available from: https:// pubmed.ncbi.nlm.nih.gov/17010224

45. Akoachere JF, Ndip RN, Chenwi EB. Antibacterial effect of Zingiber officinalis and Garcinia kola on respiratory tract pathogens East Afr. Med. J. 2002;79:588-92. Available from: https:// pubmed.ncbi.nlm.nih.gov/12630492

46. Shirin APR, Jamuna P. Chemical composition and antioxidant properties of ginger root (Zingiber officinale) Journal of medicinal plant research 2010;4(24):2674-79. Available from: https:// www.researchgate.net/publication/228476601

47. Bera K , Nosalova G , Sivova V , Ray B . Structural Elements and Cough Suppressing Activity of Polysaccharides from Zingiber officinale Rhizome Phytother Res 2016;30(1):105-11. Available from: https:// pubmed.ncbi.nlm.nih.gov/26522239

48. Sulochana K, Ginni J, Vaibhav K, Jaya PY, Samander K. Anti-viral activity of Zingiber officinale (Ginger) ingredients against the Chikungunya virus, Virus Disease 2020;31:27076. Available from: https://www.researchgate.net/ publication $/ 341173033$.

49. Ojewole J. Analgesic, antiinflammatory and hypoglycaemic effects of ethanol extract of Zingiber officinale (roscoe) rhizomes (zingiberaceae) in mice and rats. Phytoth. Res 2006;20:764-72. Availbale from: https:// pubmed.ncbi.nlm.nih.gov/16807883

50. Shoji N, Iwasa A, Takemoto T, Ishida Y, Ohizumi Y. Cardiotonic principles of ginger (Zingiber officinale Roscoe). J Pharm Sci. 1982;71(10):1174-5. Available from: https:// pubmed.ncbi.nlm.nih.gov/7143220

51. Tohma H, Gulcin I, Bursal E, Goren Ahmet, Alwasel S, Koksal E. Antioxidant activity and phenolic compounds of ginger (Zingiber officinale Rosc.) determined by HPLC-MS/ MS. Journal of Food Measurement and Characterization 2017;11:556-66. Available from https://link.springer.com/article/10.1007/ s11694-016-9423-z

52. Yahya Al, Rafatullah MA, Mossa S, Ageel JS, Parmar AMNS,Tariq M. Gastroprotective activity of ginger zingiber officinale rosc., in albino rats. Am J Chin Med 1989;17(1-2):51-56. Available from: https://pubmed.ncbi.nlm.nih.gov/2589236

53. Gokhale AB, Damre AS, Kulkarni KR, Saraf MN. Preliminary evaluation of anti-infammatory and anti-arthritic activity of S. lappa, A. speciosa and A. asoara. Phytomedicine 2002;9:433-37.
Available from: https://pubmed.ncbi.nlm.nih.gov/ 12222664

54. Chen SF, Li YQ, He FY. Effect of Saussurea lappa on gastric functions. Zhongguo Zhong Xi Yi Jie He Za Zhi 1994;14:406- 08. Available from: https:// pubmed.ncbi.nlm.nih.gov/7950225

55. Yamahara J, Kobayashi M, Miki K, Kozuka M, Sawada T, Fujimura H. Cholagogic and antiulcer effect of Saussurea radix and its components. Chem Pharm Bull 1985;33:1285-88. Available from: https://pubmed.ncbi.nlm.nih.gov/4040820

56. Pandey RS . Saussurea lappa extract modulates cell mediated and humoral immune response in mice. Der Pharmacia Lettre 2013;4(6):1868-73. Available from: https://www.researchgate.net/ publication/288717816

57. Hsu YL, Wu LY, Kuo PL. Dehydrocostuslactone a medicinal plant derived sesquiterpene lactone induces apoptosis coupled to endoplasmic reticulum stress in liver cancer cells. J Pharmacol Exp Ther 2009;329: 809-19. Available from: https://pubmed.ncbi.nlm.nih.gov/19188481

58. Nagar A, Kumar A, Gullaiya S, Singh V, Dubey V, Shrinivasan BP. Assessment of spasmolytic activity of alcoholic extract of Acillea millefolium, Rubia cordifolia and Saussurea lappa in wistar albino rats., International Research Journal of Pharmacy 2013;4(7):64-6. Available from: http:// irjponline.com/admin/php/uploads/1893_pdf.pdf

59. Negi JS, Bisht VK, Bhandari AK, Bhatt, Sati MK, Mohanty JP, Sundriyal RC. Antidiarrheal activity of methanol extract and major essential oil contents of Saussurea lappa Clarke. African journal of pharmacy and pharmacology 2013;7:474-77. Available from: https://www.researchgate.net/ publication $/ 236278187$

60. Hua-Chien Chena, Chen-Kung Chou, Shou-Dong Lee, Ju-Chun Wang, Sheau-Farn Yeh. Active compounds from Saussurea lappa Clarks that suppress hepatitis B virus surface antigen gene expression in human hepatoma cells. Antiviral Research 1995;27,(1-2):99-109. Available from: https://www.sciencedirect.com/science/article/pii/ 016635429400083K

61. Akhtar M S, Bashir S, Malik M N, Manzoor R . Cardiotonic activity of methanolic extract of Saussurea lappa Linn roots. Pak J Pharm Sci 2013;26(6):1197-201. Available from: https:// pubmed.ncbi.nlm.nih.gov/24191326

62. Somasundaram S, Sadique J, Subramoniam A. In vitro absorption of (14C) leucine during inflammation and the effect of anti inflmmatory drugs in the jejunum of rats. Biochem Med 1983;29:259-64. Available from: https:// pubmed.ncbi.nlm.nih.gov/6860324

63. Dadkar VN, Ranadive NU, Dhar HL. Evaluation of antistress (adaptogen) activity of Withania somnifera (Ashwagandha). Ind J Clin Biochem 1987;2:101-08. Available from: https:// www.researchgate.net/publication/311562722

64. Ziauddin M, Phansalkar N, Patki P, Diwanay S, Patawardhan B. Studies on the immunomodulatory 
effects of Ashwagandha. J Ethnopharmacol 1996;50:69-76. Available from: https:// pubmed.ncbi.nlm.nih.gov/8866726/

65. Sangilimuthu AY, Lukmanul HF, Sathishkumar R. Antioxidant activity of Withania somnifera (L.) Dunal by different solvent extraction methods. Journal of Pharmacy Research 2011;4(5):1428-30. Available from: http://jprsolutions.info/newfiles/ journal-file-56d52489e2d4a4.54149510.pdf

66. Malhotra CL, Das PK, Dhalla NS, Prasad K. Studies on Withania ashwagandha, Kaul. III. Mechanisms of cardioprotective effect of Withania somnifera in experimentally induced myocardial infarction. Basic Clin Pharmacol Toxicol 2004;94(4):184-90 Available from: https:// pubmed.ncbi.nlm.nih.gov/15078343

67. Vadnere GP, Patil AV, Jain SK, Wagh SS. Investigation on in-vitro Antioxidant activity of whole plant of Cassia occidentalis Linn. (Caesalpiniaceae). International Journal of Pharm Tech Research 2011;3(4): 1985-91. Available from: https://www.researchgate.net/publication/ 288293196

68. Rani MS, Emmanuel S, Sreekant MR, Ignacimuthu S. Evaluation of in vivo antioxidant and hepatoprotective activity of Cassia occidentalis Linn. against paracetamol-induced liver toxicity in rat. International Journal of Pharmacy and Pharmaceutical Sciences 2010;2(3):67-70. Available from: https://www.researchgate.net/ publication/289026389

69. Sini R, Karpakavalli M, Sangeetha PT. Analgesic and Antipyretic activity of Cassia occidentalis Linn, World Applied Sciences Journal 2010;11(10):1216-19. Available from: https:// www.researchgate.net/publication/265000294

70. Shafeen S, Reddy TS, Arafath S, Nagarjuna S, Reddy YP. Evaluation of antianxiety and antidepressant activity of Cassia occidentalis leaves. Asian Journal of Pharmaceutical and Clinical Research 2012;5:47. Available from: https://innovareacademics.in/journals/index.php/ ijcpr/article/view/15280

71. Vadnere G, Samani R, Singhai AK. Antiasthmatic potential of aqueous extract of Cassia occidentalis.Planta Medica 2006;72:297. Available from: https://www.researchgate.net/publication/ 331904383

72. Bhujbal SS, Kewatkar S, More LS, Patil MJ. Antioxidant Effects of Roots of Clerodendrum serratum Linn., Pharmacognosy Research 2009;1:294-98. Available from: https:// www.researchgate.net/publication/283922605

73. Narayanan N, Thirugnanasambantham $P$, Viswanathan S, Vijayasekaran V, Sukumar E. Antinociceptive, Anti-inflammatory and Antipyretic Effects of Ethanol Extract of Clerodendrum serratum Roots in Experimental Animals. J Ethnopharmacology 1999;65:237-41. Available from: https://pubmed.ncbi.nlm.nih.gov/ 10404422
74. Singh M K, Khare G, Iyer S K, Sharwan G, Tripathi DK. Clerodendrum serratum: A clinical approach. Journal of Applied Pharmaceutical Science 2012;2(2);11-15. Available from: https:// www.researchgate.net/publication/286873698

75. Bhujbal S, Rabindrakumar N, Ganu G, Jadhav S, Dongre Priti, Bandu Choudhary et al. Protective effects of Icosahydropicenic acid isolated from the roots of Clerodendrum serratum (L.) moon on experimental allergic asthma, Journal of complementary and integrative medicine 2010;7:1. Available from: https://www.researchgate.net/ publication/273933085

76. Ali Jimal M, Elsnoussi A, Abdalrahim A, Omar I, Zhari I, Norhayati A et al. Antioxidant, Antiangiogenic and vasorelaxant activities of methanolic extract of Clerodendron serratum (Spreng.) leaves. Journal of Medicinal Plants Research 201;6(3):348-60. Available from: https:// www.researchgate.net/publication/215469628

77. Kelm MA, Nair MG, Strasburg GM, DeWitt DL. Antioxidant and cyclooxygenase inhibitory phenolic compounds from Ocimum sanctum Linn. Phytomedicine 2000;7(1):7-13. Available from: https://pubmed.ncbi.nlm.nih.gov/10782484

78. Mediratta PK, Dewan V, Bhattacharya SK, Gupta VS, Maiti S, Sen P. Effect of Ocimum sanctum Linn. on humoral immune responses. Indian J Med Res 1998;87:384. Available from: https:// pubmed.ncbi.nlm.nih.gov/3169894

79. Singh S, Majumdar DK. Evaluation of antiinflammatory activity of fatty acids of Ocimum sanctum fixed oil. Indian J Exp Biol 1997;35:380-83. Available from: https:// www.researchgate.net/publication/13907711

80. Singh S, Taneja M, Majumdar DK. Biological activities of Ocimum sanctum L. fixed oil- An overview. Indian J Exp Biol 2007;45:403-12. Available from: https://pubmed.ncbi.nlm.nih.gov/ 17569280

81. Sood S, Narang D, Dinda DK, Maulik SK. Oral administration of Ocimum sanctum Linn. augments cardiac endogenous antioxidant and prevents isoproterenol-induced myocardial necrosis in rats. J Pharm Pharmacol 2005;57(1):127-33. Available from: https:// pubmed.ncbi.nlm.nih.gov/15651118

82. Lahon K, Das S . Hepatoprotective activity of Ocimum sanctum alcoholic leaf extract against paracetamol-induced liver damage in Albino rats. Pharmacognosy Res 2011;3(1):13-18. Available from: https://www.ncbi.nlm.nih.gov/pmc/articles/ PMC3119265

83. Bhargava KP, Singh N. Antistress activity of Ocimum sanctum Linn. Indian $\mathrm{J}$ Med Res 1981;73:443. Available from: https:// pubmed.ncbi.nlm.nih.gov/7275241

84. Ahmad NS, Farman M, Najmi MH, Mian KB, Hasan A. Pharmacological basis for use of Pistacia integerrima leaves in hyperuricemia and gout. Jounal Ethnopharmacol 2008;117:478-82. 
Available from https://pubmed.ncbi.nlm.nih.gov/ 18420362

85. Ansari SH, Ali M. Analgesic and antiinflammatory activity of tetracyclic triterpenoids isolated from Pistacia integerrima galls. Fitoterapia 1996;67:103-5. Available from: https:// eurekamag.com/research/002/753/002753741.php

86. Adusumalli S, Pusapati MR, M Sankaranarayan, Antiasthmatic activity of aqueous extract of Pistacia integerrima gall, International Journal of Pharmacy and Pharmaceutical Sciences vol 5, suppl 2, 2013. Available on http:// www.ijppsjournal.com/Vol5Suppl2/6588.pdf

87. Nayak SS, Ghosh AK, Srikanth K, Debnath B, Jha T. Antitussive activity of Abies webbiana Lindl. Leaf extract against sulphur dioxideinduced cough reflex in mice. Phytother Res 2003;17:930-2. Available on https://pubmed.ncbi.nlm.nih.gov/ 13680827

88. Nayak SS, Ghosh AK, Debnath B, Vishnoi SP, Jha T. Synergistic effect of methanol extract of Abies webbiana leaves on sleeping time induced by standard sedatives in mice and anti-inflammatory activity of extracts in rats. J Ethnopharmacol 2004;93(2-3):397-402. Available from: https:// pubmed.ncbi.nlm.nih.gov/15234784

89. Yasin M, Hussain Janbaz K, Imran I, Gilani AU, Bashir S. Pharmacological studies on the antispasmodic, bronchodilator and antiplatelet activities of Abies webbiana. Phytother Res 2014;28:1182-7. Available from: https:// pubmed.ncbi.nlm.nih.gov/15234784

90. Vishnoi SP, Basu A, Alam SKM, Somanta S, Jha T. Evaluation of the antipyretic potential of methanol extract of the leaves of Abeis spectabilis (D.Don) Spach. Natural product radiance, 2007; 6(5): 369-37. Available from: https:// www.researchgate.net/publication/234066782

91. Rai P, Rakhee K, Raghavendra Rao B. Antioxidant and antimicrobial properties of Abies webbiana and Taxus baccata L. Asian J Microbiol Biotechnol Environ Sci 2008;10(3):607-8. Available from: https://www.researchgate.net/publication/ 292835830

92. Pundir S, Tomar S, Upadhyay N, Sharma V. Antioxidant, anti-inflammatory and analgesic activity of bioactive fraction of leaves of Myrica esculenta Buch.-Ham along with its pharmacognostic and chromatographic evaluation. Int. J. Biol. Pharm. Allied Sci. 2015;4:6509-6524. Available from: https:// www.ncbi.nlm.nih.gov/pmc/articles/PMC6631742

93. Patel KG, Rao NJ, Gajera VG, Bhatt PA, Patel KV, Gandhi TR. Antiallergic activity of stem bark of Myrica esculenta Buch.-Ham. (Myricaceae). J Young Pharmacists 2010;2:74-8. Available from: https://www.ncbi.nlm.nih.gov/pmc/articles/ PMC3035891

94. Khan MY, Sagrawat H, Upmanyu N, Siddique S. Anxiolytic properties of Myrica nagi bark extract. Informa Healthcare 2008;46:757-1. Available from: https://www.researchgate.net/publication/ 232093205

95. Nhiem NX, Kiem PV, Minh CV, Tai BH, Cuong $\mathrm{NX}$, Thu VK, et al. A new monoterpenoid glycoside from Myrica esculenta and the inhibition of Angiotensis I-Converting Enzyme. Chem Pharm Bull 2010;58 :1408-10. Available from: https:// pubmed.ncbi.nlm.nih.gov/20930414

96. Aleem, A J, Khalid M, Malik H B, Samra J, Fayez R, Najeeb-ur G, et al. Pharmacological Studies on Antidiarrheal, Gut Modulatory, Bronchodilatory and Vasodilatory Activities of Myrica nagi. International Journal of Pharmacology 2015;11(8):888-98. Available from: https:// www.researchgate.net/publication/283327428

97. Lahiri PK, Pradhan SN. Pharmacological investigation of vasicinol, an alkaloid from Adhatoda vasica Nees. Indian Journal of Experimental Biology 1964;2:219. Available from: https://www.researchgate.net/publication/ 306020300

98. Paliwa JK, Dwivedi AD, Sihgh S, Gupta RC. Pharmacokinetics and in-situ absorption studies of a new anti-allergic compound 73/602 in rats. Int $\mathrm{J}$ Pharm 2000;197(1-2):213-20. Available from: https://pubmed.ncbi.nlm.nih.gov/10704808

99. Padmaja M, Sravanthi M, Hemalatha KPJ. Evaluation of Antioxidant Activity of Two Indian Medicinal Plants. Journal of Phytology 2011;3(3):86-91. Available from: https:// updatepublishing.com/journal/index.php/jp/article/ view/2232

100. Jiang T, Zhang L, Ding M, Li M. Protective Effect of Vasicine against Myocardial Infarction in Rats via modulation of oxidative stress, inflammation, and the PI3K/Akt pathway. Drug Des Devel Ther 2019;13: 3773-84. Available from: https://doi.org/10.2147/DDDT.S220396

101. Ahmad Md. F. A Study on Antipyretic Activity of Adhatoda vasica Nees Leaves' Methanolic Extract international Journal of Pharmacy and Pharmaceutical Research 2017;8(4):14-18. Available from: https://ijppr.humanjournals.com/astudy-on-antipyretic-activity-of-adhatoda-vasicanees-leaves-methanolic-extract/

102. Thomas, Toji. Antibacterial activity of Adiantum lunulatum burm. F. towards bacteria implicated in cutaneous infections. Journal of Biological \& Scientific Opinion 2013;1(4):334-36. Available from: https://www.researchgate.net/publication/ 271235349

103. Kakadia N, Amin M, Deshpande S. Hepatoprotective and antioxidant effect of Adiantum lunulatum Burm. F. leaf in alcoholinduced rat model. Journal of Complementary and Integrative Medicine 2020;17(3). Available from: https://pubmed.ncbi.nlm.nih.gov/33001852

104. Qasemzadeh MS, Hosein HM, Gharehbeglou MH, Mojtaba SM, Akhlaghdoust, MM. The Effect of Viola odorata Flower Syrup on the Cough of Children with Asthma: A Double-Blind, Randomized Controlled Trial. Journal of evidence- 
based complementary \& alternative medicine $2015 ; 20(4)$. Available from: https:// www.researchgate.net/publication/276065394

105. Tafazoli V, Shahriari M, Heydari M, Nikbakht HA, Zarshenaas MM, Nimrouzi M. The effect of viola odorata 1. Oil for fever in children: a randomized triple-blinded placebo-controlled clinical trial. Curr Drug Discov Technol 2019. Available from: https:// pubmed.ncbi.nlm.nih.gov/31250761

106. Siddqi HS, Mehmood NH, Rehman NU, Gilani AH. Studies of antihypertensive and antidyslipidemic activities of Viola odorata leaves extracts. Lipids in Health and Diseases 2012;11:6. Available from: https://www.ncbi.nlm.nih.gov/ pmc/articles/PMC3286389

107. Koochek MH, Pipelzadeh MH, Mardani H. The Effectiveness of Viola odorata in the Prevention and Treatment of Formalin-Induced Lung Damage in the Rat. Journal of Herbs, Spices and Medicinal Plants 2003;10(2):95-103. Available from: https:// www.researchgate.net/publication/233239748

108. Yi K, Bin L, Jingran F, Xue Q, Min Y. Antitussive and expectorant activities of licorice and its major compounds. Bioorg Med Chem 2018;26(1):278-84. Available from: https:// pubmed.ncbi.nlm.nih.gov/29224994

109. Sharma V, Agrawal RC, Pandey S. Phytochemical screening and determination of anti-bacterial and anti-oxidant potential of Glycyrrhiza glabra root extracts. J Environ Res Dev 2013;7(4A):1552-58. Available from: https://www.researchgate.net/ publication/272162623

110. Mendes-Silva W, Assafim M, Ruta B, Monteiro RQ, Guimaraes JA, Zingali RB. Antithrombotic effect of glycyrrhizin, a plant-derived thrombin inhibitor. Thromb Res 2003;112:93-98. Available from: https://pubmed.ncbi.nlm.nih.gov/15013279

111. Dhingra D, Parle M, Kulkarni SK. Memory enhancing activity of Glycyrrhiza glabra in mice. J Ethnopharmacol 2004;91(2-3):361-65. Available from: https://pubmed.ncbi.nlm.nih.gov/15120462

112. Liqiang W, Rui Y, Bochuan Y, Ying L, Chunsheng L. The antiviral and antimicrobial activities of licorice, a widely-used Chinese herb. Acta Pharm Sin B 2015;5(4):310-15. Available from: https:// www.ncbi.nlm.nih.gov/pmc/articles/PMC4629407

113. Adel M, Alousi LA, Salem HA. Licorice: a possible anti-inflammatory and anti-ulcer drug. AAPS Pharm Sci Tech 2005;6:74-82. Available from: https://www.ncbi.nlm.nih.gov/ pmc/articles/PMC2750414

114. Wagner H, Jurcic K. Immunological studies of Revitonil: a phytopharmaceutical containing Echinacea purpurea and Glycyrrhiza glabra root extract. Phytomedicine 2002;9(5):390 97. Available from: https://www.sciencedirect.com/ science/article/pii/S0944711304701300

115. Sowmya M, Kumar S. Antistress property of Glycyrrhiza glabra on stress induced Drosophila melanogaster. Journal of Stress Physiology \& Biochemistry 2010;6:18-27.
Available from: https://www.researchgate.net/ publication/49582934

116. Kosaraju J, Roy PD. Neuroprotective effect of Tinospora cordifolia ethanol extract on 6hydroxydopamine induced Parkinson disease. Internationa $1 \quad$ J o u rna $1 \quad$ of Pharmacology 2014;46:176-80. Available from: https://www.ncbi.nlm.nih.gov/pmc/articles/ PMC3987186

117. Kaur M, Kumar B, Singh A. Comparative antidiarrhoel \& antiulcer effect of aqueous \& ethanolic extracts of Tinospora cordifolia in rats. International Journal of Pharmaceutical Technology \& Research 2014;5: 122-8. Available from: https://www.ncbi.nlm.nih.gov/pmc/articles/ PMC4131402

118. Goel B, Pathak N. Clinical evaluation of analgesic activity of Guduchi, Tinospora cordifolia using animal model. Journal of Clinical Diagnosis \& Research 2014;8:1-4. Available from: https:// www.ncbi.nlm.nih.gov/pmc/articles/PMC4190733

119. Patgiri B, Umretia BL, Prajapati PK, Shukla VJ. Anti-inflammatory activity of aqueous extract of Tinospora cordifolia. Ayurveda 2014;35:108-10. Available from: https://www.ncbi.nlm.nih.gov/ pmc/articles/PMC4213960

120. Sharma AK, K Kishore K, Sharma D, Agarwal SS, Singh SK. Cardioprotective activity of alcoholic extract of Tinospora cordifolia in $\mathrm{CaCl} 2$ induced cardiac arrhythmia in rats. Journal of Biomedical Research 2011;25:280-6. Available from: https:// www.ncbi.nlm.nih.gov/pmc/articles/PMC3597064

121. Dhingra D, Goyel PK. Evidence for the involvement of monoaminergic \& GABAergic systems in antidepressant like activity of Tinospora cordifolia in mice. Indian journal of Pharmaceutical Sciences 2008;70:761-7. Available from: https://www.ncbi.nlm.nih.gov/pmc/articles/ PMC3040870

122. Tiwari M., Kakkar P, Dwivedi UN. Tinospora cordifolia extract modulates COX-2, iNOS, ICAM 1 , pro-inflammatory cytokines \& redox status in murine model of asthma. Journal of Ethnopharmacology 2014; 28: 326-37. Available on https://pubmed.ncbi.nlm.nih.gov/24556222

123. Ashok BK, Ravishankar B, Bhat SD. Antipyretic activity of Guduchi ghrita formulations in albino rats. Ayu 2010;31:367-70. Available from: https:// pubmed.ncbi.nlm.nih.gov/22131741

124. Badar VA, Thawani VR, Wakode PT. Efficacy of Tinospora cordifolia in allergic rhinitis. Journal of Ethnopharmacology 2005;96:445-9. Available from: https://pubmed.ncbi.nlm.nih.gov/15619563

125. Ramesh V, Jayaprakash R, Sridhar MP. Antioxidant activity of ethanol extract of Tinospora cordifolia on N-nitrosodiethylamine induced lier cancer in male wistar albino rats. Journal of Pharmaceutical \& Bioallied Sciences 2015,1:45-50. Available from: https:// www.ncbi.nlm.nih.gov/pmc/articles/PMC4439705

126. Singh G, Maurya S, DeLampasona MP, Catalan CA. A comparison of chemical, antioxidant and 
antimicrobial studies of cinnamon leaf and bark volatile oils, oleoresins and their constituents. Food Chem Toxicol 2007;45:1650-61. Available from: https://pubmed.ncbi.nlm.nih.gov/17408833

127. Nyadjeu P, Dongmo A, Nguelefack TB, Kamanyi A. Antihypertensive and vasorelaxant effects of cinnamomum zeylanicum stem bark aqueous extract in rats. Integr Med $\mathrm{J}$ Complement $2011 ; 8(1)$. Available from: https:// pubmed.ncbi.nlm.nih.gov/22754922

128. Munazza F, Nazam SZ, Deeba A, Farhan A. In Vitro Antiviral Activity of Cinnamomum cassia and Its Nanoparticles Against H7N3 Influenza A Virus 2016;26(1):151-9. Available from: https:// pubmed.ncbi.nlm.nih.gov/26403820

129. Sohrabi R, Pazgoohan N, Seresht HR, Amin B. Repeated systemic administration of the cinnamon essential oil possesses anti-anxiety and antidepressant activities in mice. Iran J Basic Med Sci 2017;20:708-14. Available from: https:// pubmed.ncbi.nlm.nih.gov/28868126

130. Kurokawa M, Kumeda CA, Yamamura J, Kamiyama T, Shiraki K. Antipyretic activity of cinnamyl derivatives and related compounds in influenza virus-infected mice. Eur J Pharmacol 1998;348:45-51. Available from: https:// pubmed.ncbi.nlm.nih.gov/9650830

131. Chandana VR, Madhavan V, K Sairam, Vikas K, Antidiarrhoeal activity of the standardised extract of Cinnamomum tamala in experimental rats, J Nat Med 2008;62(4):396-402. Available from: https:// pubmed.ncbi.nlm.nih.gov/18493839

132. Lakshmi Devi S , S Kannappan, C V Anuradha, Evaluation of in vitro antioxidant activity of Indian bay leaf, Cinnamomum tamala (Buch. -Ham.) $\mathrm{T}$. Nees \& Eberm using rat brain synaptosomes as model system, Indian J Exp Biol 2007;45(9):778-84 Available from: https:// pubmed.ncbi.nlm.nih.gov/17907743

133. Thamizhselvam N, Soumya S, Sanjayakumar YR, Salinichandran K, Jaya N. Anti-inflammatory, Analgesic and antipyretic activity of methanolic extract of Cinnamomum Tamala (Nees) in experimental Animal Models. Int J Bioas 2012;01(09). Available from: https:// www.semanticscholar.org/paper/Antiinflammatory $\% 2 \mathrm{C}$-analgesic-and-antipyretic-of-of$\mathrm{T} \mathrm{h}$ a $\mathrm{m}$ i $\mathrm{z} \mathrm{h} \mathrm{s}$ e $1 \mathrm{v}$ a $\mathrm{m}-\mathrm{S}$ o u m y a / 001375db2aa7a268d386405de3f138e0646e0bb6

134. Ullah N, Khan M, Khan T, Ahmad W. Protective Effect of Cinnamomum tamala Extract on Gentamicin-Induced Nephrotic Damage in Rabbits. Tropical Journal of Pharmaceutical Research 2013;12(2): 215- 19. Available from: https:// www.researchgate.net/publication/260230925

135. Chaurasia JK, Mishra A, Tripathi YB, Immunomodulation property of hexane fraction of leaves of Cinnamomum tamala Linn. in rats, Cell Biochem Funct 2010 Aug;28(6):454-60. Available from: https://pubmed.ncbi.nlm.nih.gov/20677178

136. Upadhyay G, Khoshla S, Kosuru R, Singh S. Anxiolytic, antidepressant, and antistress activities of the aqueous extract of Cinnamomum tamala Nees and Eberm in rats. Indian $\mathrm{J}$ Pharmacol 2016;48(5):555-61. Available from: https:// pubmed.ncbi.nlm.nih.gov/27721543

137. Kurokawa M, Kumeda CA, Yamamura J, Kamiyama T, Shiraki K. Antipyretic activity of cinnamyl derivatives and related compounds in influenza virus-infected mice. Eur J Pharmacol 1998 May;348(1):45-51. Available from: https:// pubmed.ncbi.nlm.nih.gov/9650830

138. Bandaru N, Vidhyadhara S, Kumar A, Vikas S , Evaluation of cardio protective activity of ethanolic extract of dried leaves of Cinnamomum tamala in rat, International Journal of Biomedical and Advance Research April 2016,7(4):181. Available from: https://www.researchgate.net/ publication/311446800

139. Sutovska M, Nosalova G, Franova S and Kardosova A. The antitussive activity of polysaccharides from Althaea officinalis 1., var. Robusta, Arctium lappa L., var. Herkules, and Prunus persica L., Batsch. Bratisl Lek Listy 2007;108(2):93-9. Available from: https:// pubmed.ncbi.nlm.nih.gov/17685009

140. Elmastas M, Ozturk L, Gokce I, Erenler R, AboulEnein HY. Determination of antioxidant activity of marshmallow flower (Althaea officinalis). Anal Lett 2004;37:1859-69. Available from: https:// www.researchgate.net/publication/233460039

141. Wang DF, Shang JY, Yu QH. Analgesic and antiinflammatory effects of the flower of Althaea rosea (L.) Cav. Zhongguo Zhong Yao Za Zhi 1989;14:46-8. Avaialable from: https:// pubmed.ncbi.nlm.nih.gov/2504193

142. Sayyad AZ, Gholamreza A, Azita K, Inhibitory effects of Germinal Angiotensin Converting Enzyme by Medicinal Plants Used in Iranian Traditional Medicine as Antihypertensive. Journal of Kerman University Of Medical Sciences Spring 2009;16(2):134-143. Available from: https:// www.researchgate.net/publication/342355262

143. Kumar SS, Sudhakar S, Kapil S, Snigdha T. Ethnopharmacological review on Althaea officinalis. WJPPS. 2016;5(7):425-32. Available from: https://www.wjpps.com/Wjpps_controller/ abstract id $/ 5421$

144. Jurenka JS. Anti-inflammatory properties of curcumin, a major constituent of Curcuma longa: a review of preclinical and clinical research. Altern Med Rev 2009;14(2):141-53. Available from: https://pubmed.ncbi.nlm.nih.gov/19594223

145. Kiso Y, Suzuki Y, Watanabe N, Oshima Y, Hikino H. Antihepatotoxic principles of Curcuma longa rhizomes. Planta Med. 1983;49(3):185-7. Available from: https://pubmed.ncbi.nlm.nih.gov/6657788

146. Mortellini R, Foresti R, Bassi R, Green CJ. Curcumin, an antioxidant and anti-inflammatory agent, induces heme oxygenase- 1 and protects endothelial cells against oxidative stress. Free Radic Biol Med 2000; 28:1303-12. Available from: https://pubmed.ncbi.nlm.nih.gov/10889462 
147. Dikshit M, Rastogi L, Shukla R, Srimal RC. Prevention of ischaemia-induced biochemical changes bycurcumin and quinidine in the cat heart. Indian J Med Res 1995;101:31-35. Available from: https://pubmed.ncbi.nlm.nih.gov/7883281

148. Mazumder A, Neamati N, Sunder S, Schulz J, Pertz H, Eich E, Pommier Y. Curcumin analogs with altered potencies against HIV-1 integrase as probes for biochemical mechanisms of drug action. J Med Chem 1997;40(19):3057-63. Available from: https://pubmed.ncbi.nlm.nih.gov/9301668

149. Yu ZF, Kong LD, Chen Y. Antidepressant activity of aqueous extracts of Curcuma longa in mice. $\mathrm{J}$ Ethnopharmacol 2002;83:161-5. Available from: https://pubmed.ncbi.nlm.nih.gov/12413724

150. Neha S, Ranvir GD, Jangade CR. Analgesic and antipyretic activities of Curcuma longa rhizome extracts in Wister Rats. Veterinary World 2009;2(8):304-06. Available from: https:// www.researchgate.net/publication/268411448

151. Kannan P, Wahita H. Antibacterial activity of Terminalia chebula Retz fruit extract.African journal of microbiology research 2009;3(4):180-84. Available from: https:// www.researchgate.net/publication/235706039

152. Lin LT, Chen TY, Lin SC, Chung CY, Lin TC, Wang GH, et al. Broad-spectrum antiviral activity of chebulagic acid and punicalagin against viruses that use glycosaminoglycans for entry. BMC microbiology 2013;13:187. Available from: https:// pubmed.ncbi.nlm.nih.gov/23924316

153. Cheng HY, Lin TC, Yu KH, Yang CM, Lin CC. Antioxidant and free radical scavenging activities of Terminalia chebula. Biol Pharm Bull 2003;26(9):1331-5. Available from: https:// pubmed.ncbi.nlm.nih.gov/12951481

154. Suchalatha S, Shyamala Devi CS. Protective effect of Terminalia chebula against experimental myocardial injury induced by isoproterenol. Indian J Exp Biol 2004;42(2):174-8. Available from: https://pubmed.ncbi.nlm.nih.gov/15282950 .

155. Shivaprasad HN, KharyaMD, Rana AC, Mohan S. Preliminary Immunomodulatory Activities of the Aqueous Extract of Terminalia chebula. Pharmaceutical Biology;44(1):32-4. Available from: https://www.researchgate.net/publication/ 232090538

156. Nosalova G, Jurecek L, Chatterjee UR, Majee SK, Nosal S, Ray B. Antitussive Activity of the WaterExtracted Carbohydrate Polymer from Terminalia chebula on Citric Acid-Induced Cough. Evid Based Complement Alternat Med 2013;2013:650134. Available from: https://www.ncbi.nlm.nih.gov/ pmc/articles/PMC3708419

157. Afsar S, Reddy PV, Priyanka B, Srilaxmi A, S Saisaran, Raja C. Pharmacological Evaluation Of Anti-Pyretic Activity Of Ethanolic Friut Extract Of Terminalia Chebula In Wistar Ratss International Journal of Advances in Pharmaceutical 2012;3(1):692-95. Available from: https:// www.researchgate.net/publication/268203718
158. Pratibha N, Saxena VS, Amit A, D'Souza P, Bagchi M, Bagchi D. Anti-inflammatory activities of Aller-7, a novel polyherbal formulation for allergic rhinitis. Int J Tissue React 2004;26(1-2):43-51. Available from: https://pubmed.ncbi.nlm.nih.gov/ 15573692

159. Perianayagam JB, Sharma SK, Joseph A, Christina AJ. Evaluation of anti-pyretic and analgesic activity of Emblica officinalis Gaertn. J Ethnopharmacol 2004;95:83-5. Available from: https://www.researchgate.net/publication/8339122

160. Pemminati S, HN Gopalkrishna, Shenoy AK, Sahu SS, Mishra S, Meti V, Vinod N. Antidepressant activity of aqueous extract of fruits of Emblica officinalis in mice. Int J App Biol Pharma Technol 2010;1(2):449-54. Available from https:// www.researchgate.net/publication/282860385

161. Scartezzinia P, Antognonia F, Raggib MA, Polia $\mathrm{F}$, Sabbionib $\mathrm{C}$. Vitamin $\mathrm{C}$ content and antioxidant activity of the fruit and of the Ayurvedic preparation of Emblica officinalis Gaertn. Journal of Ethnopharmacology 2006,104(1-2)8:113-18. Available from: https:// www.sciencedirect.com/science/article/pii/ S0378874105006057

162. Muthuraman A, Sood S, Singla SK. The antiinflammatory potential of phenolic compounds from Emblica officinalis L. in rat. Inflammopharmacol 2011;19:327-334. Available from: https://www.ncbi.nlm.nih.gov/pmc/articles/ PMC3227803

163. Estari M, Venkanna L, Sripriya D, Lalitha R. Human Immunodeficiency Virus (HIV-1) reverse transcriptase inhibitory activity of Phyllanthus emblica plant extract. Biology and Medicine 2012;4(4): 178-82. Available from: https:// www.researchgate.net/publication/287775035

164. Gulati RK, Agarwal S, Agrawal SS. Hepatoprotective studies on Phyllanthus emblica Linn. and quercetin. Indian journal of experimental biology 1995;33(4):261-68. Available from: https://pubmed.ncbi.nlm.nih.gov/7558182

165. Rajak S, Banerjee SK, Sood S, Dinda AK, Gupta YK, Gupta SK, Maulik SK. Emblica officinalis causes myocardial adaptation and protects against oxidative stress in ischemic-reperfusion injury in rats. Phytother Res 2004; 8(1):54-60. Available on https://pubmed.ncbi.nlm.nih.gov/14750202

166. Nosalava G, Mokry J, Hassan KM. Antitussive activity of the fruit extract of Emblica officinalis Gaertn. (Euphorbiaceae). Phytomedicine 2003;10(6-7):583-9.. Available from: https:// pubmed.ncbi.nlm.nih.gov/13678247

167. Kaushik P, Goyal P, Chauhan A, Chauhan G. In vitro evaluation of antibacterial potential of dry fruit extract of Ellatria cardamom Maton (chhoti elaichi). Iranian J Pharma Res 2010;9(3):287-97. Available from https://www.ncbi.nlm.nih.gov/pmc/ articles/PMC3863444

168. Jamal A, Javed K, Aslam M, Jafri MA. Gastro protective effect of cardamom, Elettaria cardimomum Maton. fruits in rats. J 
Ethnopharmacol 2006;103(2):149-53. Available from: https://pubmed.ncbi.nlm.nih.gov/16298093

169. Verma SK, Jain V, Katewa SS. Blood pressure lowering fibrinolysis enhancing and antioxidant activities of cardamom ( Ellatria cardamom). Indian J Biochem biophysics 2009;46:503-06,. Available from: https://www.researchgate.net/ publication/42973596

170. Singh R, Kaushik R, Jaglan V. Antibacterial and antioxidant activity of green cardamom and rosemary extract in food products: A brief review. The Pharma Innovation Journal 2018;7(6):568-73. Available from: https:// www.thepharmajournal.com/archives/? year $=2018 \&$ vol $=7 \&$ issue $=6 \&$ page $=9$

171. Sharma S, Sharma J, Kaur G. Therapeutic uses of Elettaria cardamom. International Journal of Drug Development and Research 2011;2:102-08. Available from: https:/www.researchgate.net/ publication/325618960.

172. Vayalil PK, Kuttan G, Kuttan R. Rasayanas: evidence for the concept of prevention of diseases. Am J Chin Med. 2002;30(1):155-71. Available from: https://pubmed.ncbi.nlm.nih.gov/12067090

173. Kunte A M. Ashtanga Hridaya of Vagbhata. Chikitsa Sthana. Ch. 1. Ver.3-4. Reprint ed. Varanasi: Chaukhamba Sanskrit Sansthan; 2011. p. 543-44.
174. Kunte A M. Ashtanga Hridaya of Vagbhata. Chikitsa Sthana. Ch. 1. Ver.84. Reprint ed. Varanasi: Chaukhamba Sanskrit Sansthan; 2011. p. 561.

175. Thevarajan I, Nguyen THO, Koutsakos M, Druce J, Caly L, van de Sandt CE, et al. Breadth of concomitant immune responses prior to patient recovery: a case report of non-severe COVID-19. Nat Med. 2020;26(4):453-55. Available from: https://pubmed.ncbi.nlm.nih.gov/32284614

176. Mehta P, McAuley DF, Brown M, Sanchez E, Tattersall RS, Manson JJ; HLH Across Speciality Collaboration, UK. COVID-19: consider cytokine storm syndromes and immunosuppression. Lancet. 2020;28:395(10229):1033-34. Available from: https://pubmed.ncbi.nlm.nih.gov/32192578

177. Acharya PS, editor. Charaka Samhita of Agnivesha. Chikitsa Sthana. Ch. 1. Ver.4-8. Reprint ed. Varanasi: Chaukhamba Surbharti Prakashan; 2008. p. 3-4.

178. Mokhtari T, Hassani F, Ghaffari N, Ebrahimi B, Yarahmadi A, Hassanzadeh G. COVID-19 and multiorgan failure: A narrative review on potential mechanisms. J Mol Histol. 2020 Dec;51(6):613-28. Available from: https://www.ncbi.nlm.nih.gov/ pmc/articles/PMC7533045

179. Kunte A M. Ashtanga Hridaya of Vagbhata. Sutrasthana Ch.12. Ver.67-68. Reprint ed. Varanasi: Chaukhamba Sanskrit Sansthan; 2011. p.207. 